\title{
OS EMARANHADOS FIOS DE PERTENCIMENTO
}

\section{CLAUDIA FONSECA}

\begin{abstract}
RESUMO
Examinamos, a base de pesquisas etnográficas, os emaranhados de pertencimento mediados por diferentes tecnologias que moldam identidades pessoais, familiares e de grupo. Consideramos em particular um tipo de solidariedade difusa e duradoura que cria laços entre pessoas, mobilizando emoções, afetos e sentimentos morais. Nosso universo empírico se constrói ao redor de um evento crítico - a violação dos direitos humanos de filhos e filhas de pacientes brasileiros de hanseníase que, em meados do século XX, foram internados à força - e o movimento político das vítimas visando reparação. Escolhemos três tecnologias interconectadas - documentos escritos, lembrança e testes de DNA - usadas pelos principais atores para calcular suas conexões "familiares". Essa abordagem nos permite explorar não apenas a materialidade das percepções, mas também as complexas temporalidades em jogo no processo contínuo e eternamente incompleto de "pertencer".
\end{abstract}

\section{PALAVRAS-CHAVE \\ Parentesco; Hanseníase; Memória; DNA.}

\section{TANGLED THREADS OF BELONGING}

\begin{abstract}
On the basis of ethnographic research, we examine the entanglements of belonging mediated by different technologies that shape personal, family and group identities. We consider in particular a type of diffuse and lasting solidarity that creates bonds between people, mobilizing emotions, affections and moral feelings. Our empirical universe is built around a critical event - the violation of the human rights of the sons and daughters of Brazilian leprosy patients who were forcibly interned in the middle of the 20th century - and the political movement of victims seeking redress. We choose three interconnected technologies - written documents, memories, and DNA tests - used by key actors to calculate their "family"; connections. This approach allows us to explore not only the materiality of perceptions but also the complex temporalities at play in the continuous and eternally incomplete process of belonging.
\end{abstract}

\section{KEYWORDS \\ Kinship; Leprosy; Memories; DNA.}

\section{LES FILSENCHEVÊTRÉS D'APPARTENANCE}

A la base d'un travail ethnographique de terrain, nous examinons ici les enchevêtrements d'appartenance véhiculés par de différentes technologies qui façonnent l'identité personnelle, familiale et de groupe. Nous considérons en particulier un type de solidarité diffuse et durable qui crée des liens entre des personnes, mobilisant des émotions, des affections et des sentiments moraux. Notre univers empirique est construit autour d'un événement critique - la violation des droits humains des fils et filles de patients lépreux brésiliens internés de force au milieu du XXe siècle et du mouvement politique des victimes en quête de réparation. Nous avons choisi trois technologies interconnectées - documents écrits, souvenirs et tests ADN - utilisées par les acteurs clés pour calculer leurs 
connexions "familiales». Cette approche nous permet d'explorer non seulement la matérialité des perceptions, mais également les temporalités complexes en jeu dans le processus continu et éternellement incomplet de "l'appartenance ".

\author{
RÉSUMÉ \\ Parenté; Lèpre; Mémoire; DNA.
}

\title{
LOS HILOS ENREDADOS DE PERTENENCIA
}

\section{RESUMEN}

Aquí, basado en encuestas etnográficas de campo, examinamos los hilos de pertenencia mediados por diferentes tecnologías que dan forma a las identidades personales, familiares y grupales. Consideramos en particular un tipo de solidaridad difusa y duradera que crea vínculos entre las personas, movilizando emociones, afectos y sentimientos morales. Nuestro universo empírico se basa en un evento crítico, la violación de los derechos humanos de los hijos e hijas de pacientes brasileños con lepra que fueron internados por la fuerza a mediados del siglo 20, y el movimiento político de las víctimas que buscan reparación. Elegimos tres tecnologías interconectadas (documentos escritos, recuerdos y pruebas de ADN) que utilizan los actores clave para calcular sus conexiones "familiares". Este enfoque nos permite explorar no solo la materialidad de las percepciones sino también las complejas temporalidades en juego en el proceso continuo y eternamente incompleto de la "pertenencia".

\author{
PALABRAs CLAVE \\ Parentesco; Lepra; Memoria; ADN.
}




\section{INTRODUÇÃO}

Inspirada nos Estudos de Ciência e Tecnologia, assim como na antropologia da família e do parentesco, proponho examinar neste artigo os emaranhados fios do pertencimento mediados por diferentes tecnologias que ajudam a moldar identidades pessoais, familiares e comunitárias. O universo empírico é construído ao redor de um evento crítico particular no Brasil -- a violação dos direitos humanos de filhos e filhas de pacientes de hanseníase que, em meados do século XX, foram internados à força -- e o movimento político das vítimas visando reparação. Elejo três tecnologias interconectadas usadas pelos principais atores para calcular as conexões "familiares" no centro desse drama: documentos escritos, lembrança e testes de DNA. O recurso a esses três fios de identificação e pertencimento nos permite explorar não apenas a materialidade das percepções, mas também as complexas temporalidades em jogo no processo contínuo e eternamente incompleto de "pertencer".

Ao longo desta discussão, estaremos olhando para o tipo de "solidariedade difusa e duradoura" que cria laços entre pessoas, comunidades e até cidadãos de uma nação, mobilizando não apenas emoções e afetos, mas também sentimentos morais de direito e obrigação. Ao mesmo tempo que dialogamos indiretamente com discussões anteriores sobre o parentesco "prático" e "performativo", nossa abordagem explora como a dinâmica de pertencimento pode ser entendida em termos, ao invés de estrutura ou mesmo de escolha, de mediações materiais que, assim como a memória, evoluem com o tempo.

\section{O CONTEXTO}

Por mais de cinco décadas ao longo do século XX, vítimas brasileiras de hanseníase foram compulsoriamente confinadas em mais de 40 colônias hospitalares do país, localizadas em áreas rurais isoladas. Embora os pacientes acabassem por conquistar o direito de estabelecer uniões conjugais, foi-lhes negada qualquer possibilidade de vida familiar normal. Em nome do bem-estar da criança, seus filhos foram retirados horas após o nascimento e levados para o preventório mais próximo - orfanatos construídos especialmente para as "crianças saudáveis dos pais leprosos". De acordo com as políticas institucionais, a comunicação entre pais e filhos foi mantida a um mínimo. Apenas os pais que tinham "testado negativo", comprovando que estavam livres de bactérias, obtinham permissão para uma eventual visita. E, em geral, mesmo quando conseguiram encontrar recursos para fazer a viagem até o orfanato, o contato físico com os filhos permanecia fora de questão (ver Maciel et al. 2003). 
À medida que essa política de saúde pública "esclarecida" chegava ao fim (a partir dos anos 1970), os ex-internos passaram a se unir para exigir reparação pela violação estatal de seus direitos humanos fundamentais. Rejeitando a individualização dos pleitos, o MORHAN ${ }^{1}$ (o movimento social que, durante as últimas quatro décadas, encabeça campanhas destinadas a promover o bem-estar das pessoas afetadas pela hanseníase) reuniu poderosos aliados para, depois de anos de luta, aprovar uma lei nacional em 2007 concedendo reparação aos exinternos ${ }^{2}$. Imediatamente após esta vitória política, uma nova categoria de vítimas surgiu para reclamar seus direitos: os filhos dos pacientes -- crianças enviadas para orfanatos e famílias adotivas, para viver longe de seus pais e, na maioria das vezes, em circunstâncias de pobreza.

Recolhidas pelo MORHAN de depoentes esparramados do Norte ao Sul do Brasil, as narrativas sobre a infância infeliz desses "órfãos de pais vivos" circularam amplamente na mídia, bem como em audiências públicas estaduais e federais. No entanto, existia certa dificuldade em localizar e identificar todos os filhos arrancados de suas localidades originais e dispersos no interior do país. A aparição em 2012 de um novo aliado - um grupo de geneticistas universitários - impulsionou a divulgação da história dos filhos. Com fundos de pesquisa fornecidos pelo Ministério da Ciência e Tecnologia, o "Projeto Reencontro" foi inspirado na experiência das abuelas argentinas que usaram a tecnologia de DNA para identificar seus netos sequestrados pela ditadura militar. No caso dos filhos separados brasileiros, a ideia era mais uma vez usar o DNA a serviço dos direitos humanos, validando a identidade dos filhos que, por falta de documentação, não conseguiam demonstrar seus laços familiares (PENCHASZADEH; SCHULERFACCINI, 2014). Nossa pesquisa de campo, baseada em entrevistas e observação participante em quatro estados diferentes, passou a incluir informações detalhadas sobre aproximadamente cem pessoas envolvidas nesses testes ${ }^{3}$. Inicialmente, buscávamos conhecer o impacto dos testes de DNA nas relações familiares. No entanto, as descobertas etnográficas nos levaram a ampliar o escopo de investigação para considerar diversas linhas de cálculo que mediam as noções de família e parentesco nesse universo em particular.

\section{EMARANHADOS DE PARENTESCO}

\footnotetext{
${ }^{1}$ Movimento de Reintegração das Pessoas Atingidas pela Hanseníase.

${ }^{2}$ Ver a Lei Federal 11.520 que, além de se constituir em pedido oficial de desculpas, concedeu uma pensão vitalícia aos compulsoriamente internados.

${ }^{3}$ A antropóloga, Glaucia Maricato, colaborou na maior parte dessas viagens, desenvolvendo pesquisa própria sobre o universo de afetados pela hanseníase (ver Maricato 2015 e 2019).
} 
Em nossa análise, usamos "parentesco" e "família" como termos praticamente intercambiáveis. Seria útil colocar em perspectiva minha postura - aliás, bastante comum em certos setores da antropologia contemporânea ${ }^{4}$. Houve, de fato, um momento na história da antropologia em que o parentesco e a família eram retratados como tudo menos intercambiáveis, quando cada um era visto como algo claramente delimitado - um fenômeno universal a ser dimensionado e decifrado em seus respectivos contextos. No início dos anos setenta, Jack Goody (1973) editou o que viria a ser um clássico moderno da pesquisa anglosaxônica sobre o "caráter do parentesco" (The character of kinship). Organizado em homenagem a Meyer-Fortes, os capítulos, acompanhados por gráficos genealógicos e estatísticas, debatiam questões de filiação, descendência, incesto e exogamia em uma perspectiva comparativa voltada para a construção de modelos. Nesse volume, o parentesco era representado através das conexões genealógicas que, particularmente nas sociedades tribais, eram tidas como chave no ordenamento do "domínio político-cultural" da vida. A "família", por outro lado, seria um elemento distinto, embora complementar, dessa discussão, representando a esfera doméstica mais íntima, afetiva e "natural" da reprodução sexual. Estampada na capa do livro, uma escultura por Henry Moore retrata um homem, uma mulher e duas crianças no que parece ser uma cena doméstica familiar, dando a entender algo da pesada universalidade do tema. As figuras abstratas gravadas em pedra não têm cor, nem feições distintivas. Contudo, o observador lê facilmente na cena o tom moral e afetivo da família nuclear típica das classes médias euroamericanas. A justaposição do título do livro e a imagem da capa colabora na produção de uma sensação de que, aqui, o leitor está lidando com os fatos concretos da existência.

Quase trinta anos depois, Sarah Franklin e Susan McKinnon editaram uma coletânea propondo delinear novas direções no estudo de parentesco. Seu título irônico - Relative values (valores relativos) - desafia qualquer ideia de fatos consumados, estabilizados (MCKINNON; FRANKLIN, 2001). Nela, há capítulos focados tanto nas genealogias de vida artificial, nas linhagens de cientistas e nas famílias de hiper-texto, quanto nas conexões produzidas por transfusões inter-étnicas de sangue, pela adoção internacional, por doenças genéticas e pela doação de gametas. Não é por acaso que a capa do volume ${ }^{5}$ traz o retrato de uma família pouco convencional. Três figuras em pé: atrás, um gato e um cachorro, aparentemente um casal; na

\footnotetext{
${ }^{4}$ Veja, por exemplo, EDWARDS e STRATHERN (2000), bem como a maioria dos outros capítulos do volume clássico de CARSTEN (2000), nos quais os autores, em vez de se basearem em definições prévias de família ou parentesco, experimentam termos "abertos a idiomas indígenas de relacionamento" (CARSTEN, 2000, p.4)
}

${ }^{5}$ A pintura é do artista mexicano Julio Galán. 
frente um menino, aparentemente um filho. Seus corpos, envoltos como múmias egípcias em faixas brancas de tecido, têm apenas as cabeças descobertas. O observador à procura de semelhanças familiares é deixado apenas com o olhar penetrante que essas criaturas compartilham. Assim como os autores do volume, o pintor parece brincar com a noção de parentesco, levando o leitor a territórios inesperados.

O que aconteceu, pode-se perguntar, à antropologia do parentesco durante os anos que separam esses dois clássicos? A história hoje é amplamente reconhecida: na década de 1970, os antropólogos estavam sendo expulsos de seus campos tradicionais de pesquisa por ondas sucessivas de anticolonialismo. Até então, o entendimento implícito era que a complexa álgebra do "parentesco" - com suas regras estruturais de casamento e descendência - era útil para o estudo de sociedades tribais / tradicionais, enquanto em sociedades complexas o termo "família" forneceria uma lente mais apropriada de análise. Uma vez "repatriados", os pesquisadores tinham que repensar seu postulado básico de um mundo dividido em "eles" versus "nós". David Schneider, em seu livro pioneiro, American kinship: a cultural account (1968), assumiu o desafio de estudar a sua própria cultura. Naquela obra, interpretou a obsessão norteamericana com o sexo e a biologia não como um sintoma de alta civilização, e muito menos como um retrato preciso de fatos naturais, mas sim como resultado de um sistema particular de normas e valores. Outros antropólogos, de Manchester a Stanford, seguiram no mesmo caminho investigando suas próprias sociedades. Assim, aos poucos, foi se consolidando um novo consenso - consagrado na Critique of the Study of Kinship (1984) de Schneider - de que o conceito científico de parentesco, centrado na procriação sexual, era ele mesmo um produto de valores ocidentais.

Estudiosos feministas desempenharam um papel fundamental no redirecionamento de preocupações disciplinares a partir da desconstrução dos princípios supostamente universais de gênero. Ao mesmo tempo, as novas tecnologias reprodutivas causaram uma revolução no imaginário social, junto com a visibilidade crescente de famílias adotivas e gays (COURDURIÈS; HERBRAND, 2014; UZIEL et al., 2006; ALLEBRANDT, 2011, 2015). Abertas as comportas, os pesquisadores poderiam agora abraçar o que Latour (2005) chama de perspectivas "nãomodernas", não apenas rejeitando o reducionismo biológico, mas eliminando as certezas quanto aos limites entre o "natural" e o "social"6. Hoje, em vez de trabalhar com dicotomias auto evidentes tais como "natureza" e "sociedade", "humano" e "não-humano", os analistas focam suas energias na análise das práticas através das quais essas fronteiras diferenciais são estabilizadas e desestabilizadas (BARAD, 2003).

${ }^{6}$ Ver Fonseca (2003) para maiores detalhes sobre a lugar do pensamento feminista nessas mudanças. 
Janet Carsten, em uma coletânea de 2000, amarra muitos fios dessa discussão, ao propor a noção de relacionalidade (relatedness), "usada em oposição a, ou ao lado de, 'parentesco'", para facilitar explorações inovadoras em idiomas indígenas de experiência vivida (2000, p.4). Seu interesse na presença política nas relações familiares cotidianas ganha destaque num volume posterior em que Carsten define o parentesco como um tipo particular de sociabilidade, envolvendo eventos políticos de grande escala e estruturas institucionais do Estado "em que certas formas de temporalidade e de criação de memória, e certas disposições em relação ao passado, presente e futuro são possíveis" (CARSTEN, 2007, p.5). Nessa perspectiva, as lembranças funcionam como práticas morais reveladoras que ocorrem na interface da experiência corporificada e da narrativa objetivada (LAMBEK, 2007; ver também DAS; POOLE 2004).

Jeanette Edwards e Marilyn Strathern (2000) nos aproximam ainda mais de nossas preocupações em sua análise dos instrumentos pelos quais as pessoas de uma pequena comunidade britânica calculam o pertencimento familiar. Focalizando a "interdigitação" dos relatos sociais e biológicos de relacionalidade, bem como os elementos materiais e imateriais nas redes heterogêneas de seus interlocutores, elas exploram os processos de conhecimento que conectam e cortam as redes de inclusão. Levando essa linha de investigação um passo adiante, eu perguntaria se não podemos considerar que as estradas pavimentadas e aviões a jato têm tanta influência sobre noções de família quanto sêmen ou ancestralidade genética; que bacilos podem exercer tanta agência na definição de parentes quanto narrativas compartilhadas.

Nesse sentido, cabe lembrar a natureza relacional da própria "materialidade":

"A própria natureza da materialidade é um emaranhamento. A matéria em si está sempre aberta, ou melhor, emaranhada com o "Outro". As "partes" intra-ativamente emergentes dos fenômenos são co-constituídas. Não apenas sujeitos, mas também objetos, são atravessados de lado a lado por seus parentes emaranhados ... " ( BARAD 2003, p. 818; ver também KOWAL et al. 2013; ver também LAW; MOL, 1995).

A noção de pertencimento não seria o resultado de uma rede dada de consanguíneos e afins, truncada por fatores externos, mas sim das formas momentâneas e circunstanciais de relacionalidade produzidas através de diferentes elementos (materiais e imateriais, humanos e não humanos) que compreendem os emaranhados fios de pertencimento.

\section{DOCUMENTOS, LEMBRANÇAS E DNA}

O caso de duas irmãs, Nara e Mandi, ilustra bem as complexas construções de pertencimento familiar em um contexto particular. Conheci Mandi, uma afável matrona de 
sessenta anos, em 2012, imediatamente após a audiência pública na Assembleia Legislativa de Rio Grande do Sul na qual os filhos separados narravam suas tristes histórias na esperança de que as autoridades públicas endossassem sua causa. Ao anunciar que ela havia percorrido mais de mil quilômetros para participar desse evento, tirando folga de suas atividades como vendedora ambulante de produtos de beleza, minha interlocutora se lançou nos detalhes de diferentes episódios de sua vida. As páginas amassadas que me alcançava reiteravam, por escrito, os momentos mais dramáticos. Mandi ainda não tinha festejado seu sexto aniversário quando foi separada do pai e de uma irmã e irmão mais velhos - todos os três diagnosticados no final dos anos 1950 com lepra e, sumariamente, removidos da existência dela. Antes de se mudar para outro estado, ela e sua mãe tentaram visitar seus entes queridos no hospital-colônia uma ou duas vezes. Porém, as barreiras impediam qualquer aproximação real. O contato, reduzido a um aceno de mãos e palavras gritadas através de certa distância, as deixava mais angustiadas com cada visita.

Nosso bate-papo ocorre enquanto Mandi conscienciosamente cospe no pequeno frasco de plástico fornecido pela geneticista, produzindo saliva para o teste de DNA que (ela espera) deve levar a sua inclusão na categoria de filhos separados. O desafio que ela enfrenta é construir uma prova legal de que o homem que ela descreve em seu depoimento escrito é de fato seu pai biológico. Como era frequentemente o caso na época em que nasceu, ela e seus irmãos tinham nascido em uma aldeia interiorana de pais que viviam em união consensual, e seu pai empregado agrícola sem letramento -- nunca tinha declarado qualquer um de seus filhos em cartório.

Soube, numa entrevista que realizei algum tempo depois com Nara, a irmã atingida de hanseníase, que o pai delas fora internado na Colônia antes da filha, e quando esta, ainda criança, se internou para tratamento foi um grande choque para ele: "Ele tinha dito a todo o mundo que era solteiro. Até tinha uma namorada". Nem Mandi, nem Nara conseguira que o pai fosse legalmente registrado nas suas certidões de nascimento. Mandi acabou sendo declarada em nome do segundo companheiro de sua mãe, que preencheu o lugar do pai biológico. Nara, criada na colônia, conta que não precisava de uma certidão de nascimento até que, aos 19 anos, decidiu se casar. A essa altura, seu pai havia morrido e, para sua frustração, as autoridades a registraram de "paternidade desconhecida", declarando-a a filha "natural" de uma mãe solteira. O teste de DNA que as duas mulheres realizavam para demostrar sua irmandade biológica parecia ser um primeiro passo na tentativa de corrigir seu histórico genealógico, e, assim, aproximá-las dos benefícios que cabiam aos filhos separados. 
As esperanças depositadas no teste genético falam dos incrivelmente complicados caminhos que as pessoas devem trilhar quando desejam adaptar as experiências do passado às exigências atuais para o reconhecimento legal dos laços familiares (FINE, 2008). Existem casos mais simples, como o das duas filhas de Nara, nascidas durante o internamento dela na colônia. Graças às estruturas burocráticas relativamente eficientes do Hospital-Colônia do Rio Grande do Sul no fim dos anos 70, as meninas não têm nenhum problema em apresentar documentos atestando do fato de que nasceram de uma paciente institucionalizada de hanseníase, e que, imediatamente depois do parto, foram separadas de sua mãe, e levadas para o orfanato dedicado exclusivamente às "crianças saudáveis" dos pacientes.

No entanto, muitos (se não a maioria) dos filhos separados não possuem documentação tão convincente. Consideremos o caso de Joice, outra filha que conheci na audiência pública. Nascida em Santa Catarina nos anos 60, conta que chegou num preventório pela primeira vez quando tinha três anos de idade, quando sua mãe - já em fase avançada da doença -- foi internada na Colônia vizinha. Após a morte de sua mãe, a menina foi expulsa do preventório, sendo enviada para a casa de sua avó materna. Quando esta faleceu pouco tempo depois, Joice passou para a família de certa tia. Mas, a tia também adoeceu de hanseníase, e Joice - junto com suas irmãs adotivas - foi mais uma vez enviada ao preventório. Embora separada abruptamente não uma, mas duas vezes de seus cuidadores parentais, e ela mesma institucionalizada em preventórios, Joice ainda não conseguiu documentar sua história. Goteiras e incêndios nos arquivos históricos do orfanato, junto com certa indiferença administrativa, há muito já extinguiram qualquer registro escrito da presença de Joice na instituição. Sua certidão de nascimento traz o nome de sua avó como genitora oficial. Sua tia ainda vive e, munida de certidões adequadas e depoimentos orais persuasivos, a mulher conseguiu inscrever suas filhas biológicas no pleito dos filhos. No entanto, seu status de mãe adotiva nunca foi oficializado, razão pela qual Joice permanece suspensa no limbo legal.

O caso de Mandi é ainda outro. Ela nunca foi enviada para o orfanato, mas sim criada pelo segundo marido de sua mãe -- o homem que ela chama de "pai" e que oficialmente consta como genitor em sua certidão de nascimento. Durante anos, Mandi não viu nenhum inconveniente nesse detalhe tecnicamente falso de seu documento legal de identidade. Ele apenas ratificava a relação familiar que ela havia vivido durante a maior parte de sua existência. Foi uma mudança de ambiente político, trazendo esperança de reparação financeira para os filhos, que a inspirou a tentar reescrever seu passado, mudar sua certidão e registrar um homem diferente como pai. Da mesma forma, Nara viveu por quase vinte anos sem qualquer certidão de nascimento, até a véspera de seu casamento quando as exigências da burocracia estatal 
tornaram inconveniente a falta desse documento. E quando resolveu finalmente tirar uma certidão, ela não estava especialmente interessada em colocar o nome de seu pai biológico no registro (ela teria ficado contente se seu pai adotivo tivesse aceitado esse papel). Ela estava mais preocupada com as conotações morais de ser uma criança sem pai.

Sugerimos que essas histórias evocam diferentes modos de pertencimento familiar que são relevantes não apenas para as pessoas afetadas pela hanseníase, mas também para grande parte da população rural do Brasil até meados do século XX. Aqui, a experiência de uma doença debilitante como hanseníase se somou a uma longa lista de aflições (pobreza, migrações, morte e instabilidade conjugal) que já dificultavam a vida, exigindo uma rede extensa de cooperação рага garantir a sobrevivência dos mais fracos. Assim, a circulação de uma criança entre as casas dos pais, avós, padrinhos, vizinhos e conhecidos era prática comum (FONSECA, 2002). Se alguma escola ou hospital cobrava a certidão de nascimento da criança, muitos dos pais adotivos analfabetos ou mal-acostumados com a burocracia escrita - simplesmente seguiam o caminho mais conveniente, tirando a certidão como se fossem, eles, os genitores. Essa "adoção à brasileira", embora tecnicamente ilegal, era extremamente comum e, na maioria dos casos, parecia satisfazer as necessidades dos envolvidos.

Desde o final da década de 1960, com a expansão do sistema público escolar, a palavra escrita entrou na vida do brasileiro comum. A administração pública passou a exigir a identificação documental de cada indivíduo para ratificar os atos cívicos de rotina. A crescente presença do governo no cotidiano das pessoas - desde a pressão exercida sobre pais divorciados рага pagar a pensão alimentícia do filho até o pagamento de "bolsa família" para mães de crianças em idade escolar - tornou a documentação oficial das relações familiares a condição sine qua non de acesso a muitos direitos cidadãos. Nesse sentido, a preocupação de Nara e Mandi com a demonstração documental de suas conexões familiares é apenas mais um elemento na negociação entre os indivíduos e o Estado sobre a definição de quem pertence a que família.

Percebemos, então, como o lugar da escrita na vida cotidiana, assim como a maneira em que os documentos são feitos, preservados e recuperados são coisas que mudaram substancialmente nas últimas décadas. Ainda mais, essas evidências no papel continuam se ajustando conforme as percepções dos sujeitos sobre suas experiências vividas. Assim, cabe introduzir nessa análise um segundo fio do emaranhado - lembranças. Veremos a seguir a memória dos sujeitos não como algo fixo, a ser "recuperado" ou "preservado". Materializadas através de narrativas e práticas circunstanciadas, as lembranças - assim como os documentos passam por modificações ao longo do tempo, produzindo subjetividades nem sempre previsíveis. 


\section{MEMÓRIAS MATERIALIZADAS; PARENTESCOS PERFORMADOS}

Segundo Mandi, as duas irmãs passaram quase vinte anos sem contato. A mãe das meninas se mudou para outro estado, perto de Foz Iguaçu, onde seu segundo marido tinha encontrado terra para cultivar. Embora estável, a renda modesta do casal não permitia a extravagância de uma visita interestadual. Nem telefonemas, nem cartas parecem ter sido acionados para manter contatos (apesar de ambas as mulheres terem ensino fundamental completo). Foi somente no final dos anos 1970, quando um compadre da mãe de Mandi passou pela cidade, que a família soube que Nara, agora casada e mãe de dois filhos, ainda morava na Colônia. Como Mandi diz, ela não pensou duas vezes: "Peguei um avião e fui atrás dela".

O problema era que a irmã dela, a princípio, não recebeu bem a ideia do reencontro: "Quando bati na porta, ela olhou e disse: 'Ah, É você', e bateu a porta na minha cara". De fato, pesquisas sugerem que os moradores da colônia nem sempre nutriam uma nostalgia romântica por seus parentes de sangue ou mesmo pelas crianças retiradas e criadas em outro lugar (BARCELOS; BORGES, 2000; FONSECA, 2015). Quando, no início dos anos 80, as autoridades sanitárias decidiram fechar os preventórios espalhados pelo país e reintegrar os internos em suas famílias originais, seus esforços foram recebidos com reações mistas. Um interlocutor relata como seu pai, quando soube que os filhos estariam voltando para seus cuidados, reagiu:

Conforme minha mãe nos falou, ele disse: "Filhos? Que filhos? O governo os levou embora, deixe o governo acabar de criá-los!"

Há também farto registro de mães se queixando da dificuldade em se relacionar com crianças que tinham crescido no orfanato. Uma mulher me confiou que seus filhos pareciam não ter desenvolvido os "sentimentos normais" de devoção filial. De maneira semelhante, muitos dos filhos contam como, ao contrário dos sonhos românticos que nutriam sobre a vida com suas famílias biológicas, ao retornarem "para casa", tiveram que enfrentar uma disciplina parental opressiva em condições austeras. Alguns dão voz ao sentimento de que, de um jeito ou de outro, as circunstâncias os condenaram a viver com estranhos.

Nara, internada quando criança, descobrira que os parentes de sangue eram essencialmente irrelevantes. Acolhida por um casal de pacientes, ela se lembra de seu pai biológico simplesmente como "um paciente que me trazia bananas de vez em quando". E não havia dúvida em sua mente de que, tendo crescido, casado e parido filhos ainda sem notícias de sua mãe, ela havia sido abandonada por aquela parte de sua família. Suas relações relevantes, pode-se dizer, eram seus vários vizinhos na colônia - pessoas que a criaram, a deram em casamento e batizaram seus filhos, compartilhando os rituais familiares, do nascimento ao 
túmulo. O problema era que Nara e seu marido, uma vez declarados "curados", estavam ansiosos por contatos fora da instituição que pudessem ajudá-los na adaptação a uma nova vida em que suas filhas, agora com cinco e seis anos de idade, seriam incluídas. As meninas tinham vivido desde o nascimento no orfanato, mas, graças à descoberta de medicamentos adequados e à cura oportuna de sua doença, Nara conseguira manter contato com elas e ansiavam por uma maior convivência antes que surgissem sinais de alienação emocional. Assim, quando Mandi apareceu à sua porta, oferecendo uma casa -- e até emprego na lavoura --, Nara superou seu ressentimento e aceitou o convite.

O casal e suas filhas mudaram para sua nova casa perto de Foz Iguaçu, onde viveram por onze anos - até que o marido de Nara, passando por uma piora nas sequelas da doença, foi obrigado a voltar à Colônia para receber assistência médica e social. Embora a instituição não estivesse mais admitindo novos residentes, os moradores antigos - aqueles que nunca tinham saído da instituição - exerceram grande pressão para que a administração deixasse voltar o casal de velhos amigos. Assim, Nara e seu marido, reintegrados à comunidade, voltaram para casa.

Insistimos na ideia de que as circunstâncias especiais da vida da colônia sublinham modos de pensar "família" que não eram incomuns entre os trabalhadores rurais sem terra há cinquenta anos. Sempre em movimento em busca de trabalho, as pessoas muitas vezes viviam longe de sua terra natal. Dada a dificuldade e o custo das viagens, bem como a falta de formas acessíveis de comunicação, a distância geográfica indicava o término efetivo das relações. Ao falar de sua infância, muitos dos meus interlocutores minimizavam a importância de parentes próximos que mal mereciam menção entre suas múltiplas lembranças. Tampouco possuíam fotos ou objetos herdados dos avós que pudessem suscitar narrativas ou fazer reviver conexões genealógicas.

Depois que sua mãe mudou para outro estado, Nara nunca mais viu ou recebeu notícias dela. No final dos anos 1970, quando o padrinho de Mandi, no decorrer de uma viagem de negócios, resolveu procurar sua comadre (a mãe das meninas) descobriu que esta havia morrido. No entanto, Mandi, agora uma mulher adulta, estava mais do que satisfeita com a chegada de seu padrinho - ansiosa até para buscar esse reencontro com seu passado. Apoiada em sólidas habilidades de letramento, relativa estabilidade socioeconômica e transporte acessível, ela conseguiu performar a relação de parentesco com sua irmã. Alguns observadores podem ler nesta cena estruturas clássicas de parentesco - o poder duradouro das relações de sangue e parentesco rituais. Contudo, a pergunta se coloca: antes de as mudanças econômicas e tecnológicas tornarem a comunicação e as viagens viáveis, qual relevância tinham essas estruturas na vivência diária dos sujeitos? Sugerimos que a própria noção de laço familiar é 
coproduzida por circunstâncias particulares, materializada nesse caso através de uma combinação de lembranças e novas tecnologias.

Por outro lado, para Nara, a irmã institucionalizada, as materialidades com as quais lidava tinha a ver com corpos, bacilos, serviços de saúde e medicamentos. Foi a suscetibilidade de seu corpo à hanseníase, juntamente com a política de saúde autoritária do governo, que originalmente provocou uma separação entre as duas irmãs. Foram a interação de seu corpo, os bacilos e certos tratamentos químicos que permitiram que Nara mantivesse laços com seus próprios filhos. Graças a importantes avanços médicos introduzidos durante o final dos anos 1960, ela foi capaz de prevenir as sequelas debilitantes da doença. Não mais contagiosa e sem deformidades que pudessem amedrontar as crianças, ela teve acesso regular a suas filhas no orfanato. Encorajada pelas freiras que dirigiam a colônia, bem como as do orfanato, ela aspirava ter uma vida familiar "normal". Рara isso, foi obrigada a explorar um recurso em potencial: o vínculo de sangue com sua irmã.

Quase uma dúzia de anos depois de Nara se mudar para Foz Iguaçu, o bacilo voltou a ser um ator decisivo na sua vida, reconfigurando noções de pertencimento. Apesar de tecnicamente curado, o corpo de seu marido estava passando por reações debilitantes aos bacilos mortos que permaneciam em seus tecidos. Diante da necessidade de cuidados médicos intensivos, a relação do casal com Mandi se tornou secundária. Agora, Nara e seu marido encontraram apoio duradouro na comunidade de amigos que haviam formado na Colônia pessoas que, tal como eles, sofriam dos efeitos de uma doença crônica. A profundidade temporal dessa conexão se materializou não só na biossocialidade criada pela experiência comum da doença (AURELIANO, 2015), mas também na prática do cuidado, característica por excelência do ethos de parentesco (LAMBEK, 2007).

\section{DNA - A PROVA CABAL?}

Em 2012, o MORHAN, trabalhando através de capítulos locais entusiasmados, estava mobilizando os filhos, reabrindo episódios quase apagados da memória dos indivíduos e, com isso, ajudando a consolidar um sentimento de comunidade. O movimento social havia recebido um sinal positivo de autoridades do governo nacional, otimistas quanto à possibilidade de герагас̧ão рага os filhos. É nesse contexto político que os depoimentos pessoais estavam chegando ao olhar público. É também nesse contexto que os exames genéticos atestando as conexões biológicas de família se tornaram uma questão vital para identificar quem seria elegível para benefícios. 
A ironia é que ninguém pode garantir que o exame de DNA se tornará legalmente relevante. Por exemplo, sem a documentação necessária, como o teste ajudará a identificar Mandi como um filho separado? Pode corroborar o depoimento das mulheres - afirmando que são irmãs. No entanto, o pai - que, como ex-interno da colônia, seria o protagonista em seu pleito por reparação - faleceu há muito tempo. Como a equipe genética não pretende trabalhar com exumações, existe pouca chance de comprovar a filiação paterna das meninas. Mesmo para os outros filhos, os resultados do DNA ainda estão na fase preliminar de um fato consequente. Ainda não existe lei concedendo qualquer tipo de reparação - financeira ou outra - aos filhos. Se um dia tal lei for aprovada, resta saber exatamente que importância será dada aos testes genéticos realizados por uma equipe de profissionais acadêmicos sem mandato judicial. No entanto, apesar de tudo, o processo ritual de cuspir em uma proveta tem uma efetividade: evoca a ideia de que todos os esforços estão sendo feitos para estabelecer a "verdade real" do passado, corrigindo registros e reparando injustiças.

Em outras palavras, o teste genético parece exercer efeitos importantes independentemente de sua validade legal. Os coordenadores do Morhan, referindo-se ao tremendo apelo popular do DNA, descrevem como os testes aumentam a cobertura da mídia ao mesmo tempo em que garantem uma audiência considerável nas reuniões do movimento nas quais as histórias do passado são construídas, recontadas e transmitidas. O DNA é, portanto, um ingrediente ativo na versão coletiva de eventos passados. Serve como força agregadora, literalmente unindo as pessoas. Irmãos e irmãs afastados uns dos outros há anos são colocados em contato porque um deles precisa validar, através do exame de DNA, sua ligação familiar. As pessoas parecem crer que o teste genético representa uma forma mais sólida, duradoura e especialmente - legalmente reconhecida de registrar laços de parentesco do que qualquer tecnologia anterior. Não surpreende que certo filho de meia-idade e sua irmã tinham passado oito horas na estrada para assistir a uma das audiências públicas do movimento. Apesar do fato de esses irmãos possuírem prova documental de seu vínculo familiar, ele estava empenhado em registrar sua conexão através de um teste de DNA. Como ele disse: "Como podemos ter certeza de que, daqui a alguns anos, os documentos valerão alguma coisa? Estou pensando que, no futuro, a única prova válida de identificação será o teste de DNA".

Talvez o efeito mais marcante causado pela introdução do DNA tenha a ver com uma forma de sociabilidade que abrange a vida e a morte, estendendo-se para o futuro. Inspirados na experiência argentina, os geneticistas do Projeto Reencontro estão construindo um banco de dados composto por amostras genéticas extraídas dos filhos, na esperança de que algum parente ainda não descoberto apareça. A esperança é ainda mais pungente no caso de parentes 
supostamente mortos há muito tempo. Durante os anos de internação, não era incomum os pais receberem a notícia de que seu bebê enviado para o orfanato tinha morrido. Mesmo assim, as pessoas me dizem, nenhuma prova tangível da morte da criança lhes era apresentada - nenhum atestado de óbito, nem um "tumulozinho" para ser visitado. Meus interlocutores aprenderam através de histórias na imprensa como, naquela época, os orfanatos podiam conduzir operações secretas, fornecendo crianças para adoção em troca de grandes somas de dinheiro. E eles se perguntam se a morte da criança relatada pelo orfanato não era simplesmente uma dissimulação para esse tipo de operação ilegal.

Nesse caso, o teste de DNA opera uma espécie de acoplamento moral entre, por um lado, o reconhecimento do "fato" da conexão biológica e, por outro, o reconhecimento da interferência criminal do Estado no que poderia ter sido uma vida familiar normal. A culminação deste processo é projetada para o futuro - uma espécie de dia de julgamento final. Quando os supostamente mortos voltarem à vida, as famílias serão reunidas, e os filhos finalmente receberão sua justa compensação do estado brasileiro na forma de desculpas e reparação financeira.

\section{EMARANHADOS PRODUTIVOS}

Os estudiosos contemporâneos de parentesco enfrentam o desafio um tanto inquietante de escrever sobre um assunto cuja própria existência eles questionam. Não é coincidência que volumes recentes sobre o tema proponham ir "além do parentesco" ou de alguma forma "expandir" a noção, ao mesmo tempo em que professam evitar definições préestabelecidas (BAMFORD; LEACH, 2009). É assim que os investigadores contemporâneos evocam as linhas fluidas de parentesco, sublinhando não só os variados códigos e / ou o compartilhamento de substâncias através das quais os laços de parentesco são construídos, mas também as diferentes maneiras pelas quais estes podem ser construídos, fortalecidos ou enfraquecidos dependendo das circunstâncias.

Com notáveis exceções (ver, por exemplo, JARDIM, 2016; MCCALLUM; BUSTAMENTE, 2012; SCOTT, 2011; STRAW et al., 2016; UZIEL et al., 2006), tanto no Brasil como em outros lugares - os estudos sobre parentesco, geralmente centrados em sociedades tribais ou rurais, têm como premissa a relativa estabilidade do grupo observado. Lidando com a internação compulsória de pacientes com hanseníase e a separação forçada de membros da família, somos levados a considerar como eventos críticos interrompem a vida rotineira e geram novos modos de ação. No entanto, também sugerimos que a ruptura ocasionada pela doença e pelo internamento não indica necessariamente uma experiência muito diferente da de outros 
trabalhadores sem-terra que viviam em meados do século passado. Falar de "ruptura" pode reforçar a ideia de que normalmente estamos lidando com fazendeiros que viviam em comunidades bem delimitadas com convicções firmes sobre conexões genealógicas. O que acontece se, ao invés de pressupor uma estrutura latente, sublinhamos modos de produzir sentimentos e formas de reconhecimento do pertencimento familiar? É precisamente para efetuar esse deslocamento (da estrutura latente para a dinâmica social em constante evolução) que insistimos em fios de pertencimento - variados processos animados pela mediação de mecanismos palpáveis que, em constante mutação, nunca são totalmente previsíveis.

Não há nada de etéreo nesses fios. Estão enredados em fenômenos concretos situados no tempo e no espaço - documentos danificados, adulterados ou perdidos; aviões e telefones celulares que fazem viver certas lembranças; corpos suscetíveis a assaltos microbianos; frascos de cuspe associados a um código de DNA que pode ou não ter relevância no futuro ... Essas materialidades não são projetadas aqui como meros adjuntos destinados a facilitar ou impedir a manifestação de estruturas profundas. Não são "variáveis contextuais" que podem produzir variações sobre um tema de longa duração. Nem fornecem um mero "pano de fundo" para o grande drama dos valores familiares. São co-construtores ativos de sensibilidades particulares ligadas à ideia de pertencimento. Estão emaranhados nas temporalidades de redes sociotécnicas onde a agência humana não é nem marginalizada nem central. Nessa perspectiva, a identidade pessoal e os vários modos de identificação estão inextricavelmente entrelaçados. No terreno achatado de nossa análise, todas as atribuições - sejam elas burocráticas, narrativas ou científicas - são "indígenas".

É evidente que, para brasileiros como Mandi e Nara, a sofisticação e disseminação de tecnologias legais e genéticas produziram, em um dado momento, um interesse marcante por uma "família" definida pelos laços de sangue. Mas esse interesse é estreitamente ligado a um movimento político que constitui outra comunidade de pertencimento - filhos de vítimas de hanseníase, cujos direitos humanos fundamentais foram violados pelo Estado. É para validar seu pertencimento a essa comunidade que Mandi e Nara são obrigadas a apresentar provas de sua conexão genealógica. Devemos ter cuidado, no entanto, em não projetar esse "emaranhado" específico de fios de pertencimento sobre situações do passado, nem pressupor dinâmicas de cima para baixo que explicariam o comportamento de populações inteiras de acordo com os ditames legais das autoridades governamentais. Em outras circunstâncias, os cálculos relevantes de pertencimento podem favorecer laços não biológicos: uma mãe ou pai adotivo, pessoas que sofrem de uma doença semelhante, uma comunidade de vizinhos solidários... É evidente aqui 
como "pertencer" é mediado por muitos fios emaranhados, dos quais o vínculo genealógico do parentesco clássico é apenas um dos muitos conectores materiais e imateriais possíveis.

\section{REFERÊNCIAS}

ALLEBRANDT, Débora. Perspectives théoriques dans l'étude de la famille, de l'enfance et de la parenté: un regard à partir de la comparaison entre adoption et P.M.A. Vibrant, Virtual Brazilian Anthropology, v.8, n.2, p.113-139, 2011.

ALLEBRANDT, Débora. La science de la parente: adoption, génétique et identité parmi les adoptes au Brésil. Vibrant, Virtual Brazilian Anthropology, v.12, n.1, p.141-166, 2015.

AURELIANO, Waleska de Araújo. Health and the Value of Inheritance: The meanings surrounding a rare genetic disease. Vibrant, Virtual Brazilian Anthropology, v.12, n.1, p.109-140, 2015.

BAMFORD, Sandra e James LEACH (Orgs.). Kinship and beyond : the genealogical model reconsidered. New York: Berghan Books, 2009.

BARAD, Karen. Posthumanist Performativity: Toward an Understanding of How Matter Comes to Matter. Signs: Journal of Women in Culture and Society, v. 28, n. 3, p.801-830, 2003.

BARCELOS, Artur; BORGES, Viviane. Segregar para curar? A experiência do Hospital Colônia Itapuã. Boletim da Saúde, v. 14, n. 1, p. 143-158, 2000.

CARSTEN, Janet. Cultures of relatedness. New approaches to the study of kinship. Cambridge: Cambridge University Press, 2000.

CARSTEN, Janet. Ghosts of memory: essays on remembrance and relatedness. Oxford: Blackwell Pbs., 2007.

COURDURIÈS, Jérome; Cathy HERBRAND. Genre, parenté et techniques de reproduction assistée: bilan et perspectives après 30 ans de recherche. Enfances, familles, générations, n.21: p xxviii-xliv, 2014.

DAS, Veena; POOLE, Deborah (Orgs.). Anthropology in the Margins of the State. Santa Fe: School of American Research Press, 2004.

EDWARDS, Jeanette; STRATHERN, Marilyn. "Including our own". In: J. Carsten (Org.). Cultures of relatedness: new approaches to the study of kinship. Cambridge: Cambridge University Press. pp. 149-166, 2000.

FINE, Agnès (org.). Etats civils en questions: papiers, identités, sentiment de soi. Paris :Editions du CTHS, 2008.

FONSECA, Claudia. Caminhos da adoção. São Paulo: Editora Cortez, 1995. 
FONSECA, Claudia. De Afinidades a Coalizões: uma reflexão sobre a "transpolinização" entre gênero e parentesco entre décadas recentes da Antropologia. Ilha Revista de Antropologia. Florianópolis: UFSC. v. 5, ก. 2, 2003.

FONSECA, Claudia. Time, DNA and documents in family reckonings. Vibrant, Virtual Brazilian Anthropology, v.12, n.1, p.75-108, 2015.

FRANKLIN, Sarah; MCKINNON, Susan. Relative values: reconfiguring kinship studies. Durham \& London: Duke University Press, 2001.

GOODY, Jack (Org.). The character of kinship. Cambridge: University of Cambridge Press, 1973.

JARDIM, Denise. Imigrantes ou refugiados. As técnicas de governabilidade e o êxodo dos palestinos rumo ao Brasil no século XX. Horizontes Antropológicos, v.22, n.46, p. 243-271, 2016.

KOWAL, Emma; RADIN, Joanna; REARDON, Jenny. Indigenous body parts, mutating temporalities, and the half-lives of postcolonial technoscience. Social Studies of Science, n. 43: 465-483, 2013.

LAMBEK, Michael. "The cares of Alice Alder: recuperating kinship and history in Switzerland." In: CARSTEN, Janet (org.). Ghosts of memory: Essays on remembrance and relatedness. Oxford : Blackwell Pbs., 2007, p. 218-240.

LATOUR, Bruno. Reassembling the social: an introduction to actor-network-theory. Oxford: Oxford University Press, 2005.

LAW, John; MOL, Annemarie. Notes on Materiality and Sociality. The Sociological Review, v.43, n.2, p. 274294. London, 1995.

MACIEL, Laurinda Rosa; OLIVEIRA, Maria Leide Wand-del-Rey de; GALLO, Maria Eugênia N.; DAMASCO, Mariana Santos. Memória e história da hanseníase no Brasil através de depoentes (1960-2000). História, Ciências, Saúde-Manguinhos 10 (supl.1), p.308-336, 2003.

MARICATO, Glaucia. Ordenando sujeitos e constituindo fatos: histórias performadas no pleito por direitos. In: MACHADO, H.; FONSECA, C. (Orgs.). Ciência, identificação e tecnologias de governo. Porto Alegre: Editora da UFRGS/CEGOV, 2015, p.96-120.

MARICATO, Glaucia. História sem fim: Sobre dobra e políticas ontológicas de um "mundo sem hanseníase". Tese de Doutorado em Antropologia Social, Universidade Federal do Rio Grande do Sul. Porto Alegre, 2019.

MCCALLUM, Cecilia; BUSTAMANTE, Vania. Parentesco, gênero e individuação no cotidiano da casa em um bairro popular de Salvador da Bahia. Etnográfica, v.16, n.2, p. 221-246, 2012.

PENCHASZADEH, Victor; SCHULER-FACCINI, Lavinia. Genetics and human rights. Two histories: Restoring genetic identity after forced disappearance and identity suppression in Argentina and after compulsory isolation for leprosy in Brazil. Genetics and Molecular Biology, n.37 (suppl. 1), p. 299-304, 2014. 
SCHNEIDER, David. American kinship: a cultural account. Chicago: the University of Chicago Press, 1968 (1980).

SCHNEIDER, David. A critique of the study of kinship. Ann Arbor: Univ. of Michigan Press, 1984 (1992).

SCOTT, Parry. Families, nations and generations in women's international migration. Vibrant, Virtual Braz. Anthropology, v. 8, n.2, p.279-306, 2011.

UZIEL, Anna Paula; MELLO, Luiz; GROSSI, Miriam. Conjugalidades e parentalidades de gays, lésbicas e transgêneros no Brasil. Revista de Estudos Feministas, v.14, n.2, p.481-487, 2006.

Recebido em . Aprovado em . 